\title{
Performance Improvement of Polyvinyl Formal Based Gel Polymer Electrolyte for Lithium-Ion Batteries by Coating $\mathrm{Al}_{2} \mathrm{O}_{3}$
}

\author{
Yan Wen, Gaofeng Li, Pingping Zhang, Guohong Xiong \\ Beijing Orient Institute of Measurement and Test, Beijing, China \\ Email:wenyan88415@126.com
}

Received 30 November 2015; accepted 13 February 2016; published 17 February 2016

\begin{abstract}
$\mathrm{Al}_{2} \mathrm{O}_{3} / \mathrm{PVFM} / \mathrm{Al}_{2} \mathrm{O}_{3}$ trilayer membranes are prepared by means of simple coating of $\mathrm{PVA}-\mathrm{Al}_{2} \mathrm{O}_{3}$ solution onto both sides of PVFM thin membranes, which is prepared via phase inversion method. The characteristics of the trilayer membranes and gel polymer electrolytes are investigated using FESEM, tensile testing apparatus, thermal shrinkage test, EIS and charge-discharge test. When inorganic $\mathrm{Al}_{2} \mathrm{O}_{3}$ particles are used to coat the PVFM membrane, drawbacks associated with gel-type membranes, namely, poor mechanical strength and thermal stability are greatly improved. Lithium ion cell with the $\mathrm{Al}_{2} \mathrm{O}_{3} / \mathrm{PVFM} / \mathrm{Al}_{2} \mathrm{O}_{3}$ based GPE matched with $\mathrm{LiFePO}$ shows excellent electrochemical performance.
\end{abstract}

\section{Keywords}

Phase Inversion Method, Polyvinyl Formal, Polyvinyl Alcohol, Gel Polymer Electrolyte, Aluminum Oxide

\section{Introduction}

Many gel polymer electrolytes comprising polymer matrices, plasticizing organic solvents and lithium salts have been intensively studied for applications in rechargeable lithium batteries and other electrochemical devices [1][3]. Gel polymer electrolytes in the form of very thin membranes act simultaneously as transport for lithium ions, separator, and binder between the anode and cathode electrodes [4]. Although gel polymer electrolytes with high ionic conductivity can usually be achieved by adding large amounts of organic solvents, they do not have sufficient mechanical ruggedness to withstand winding and stacking during manufacturing [5]-[7], which may cause internal short-circuiting or lead to thermal runaway [8]. These drawbacks of gel polymer electrolytes hinder their application in large-scale applications.

Polyvinyl alcohol and its derivatives have been widely noted for their advantages in their excellent thin-film forming ability, good heat- and water-resistance and relatively stable chemical structure. In recent years, polyvinyl acetal based gel polymer electrolytes have aroused much interest, Japan SONY [9], Mitsui Chemicals [10] and other companies have applied for patents successively about the polyvinyl acetal based gel polymer lithium- 
ion batteries via in-situ polymerization process.

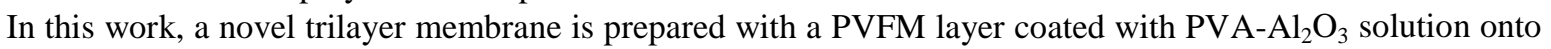
both sides to obtain the synergistic effects from each layer. This unique approach to the manufacture of trilayer membrane overcomes the drawbacks of gel-type membranes, that include poor mechanical strength and thermal stability in the electrolyte saturation state.

\section{Experimental}

\subsection{Preparation of $\mathrm{Al}_{2} \mathrm{O}_{3} / \mathrm{PVFM} / \mathrm{Al}_{2} \mathrm{O}_{3}$ Trilayer Membranes}

Polyvinyl formal (PVFM, $\mathrm{M}_{\mathrm{W}}$ : 70,000, Aldrich) powder was dissolved in N-methyl pyrrolidone (NMP, SCRC) to obtain a homogenous solution with the aid of magnetic stirrer. Chemical cross-linking agent 4,4'-diphenylmethane diisocyanate (MDI, Alfa Aesar) was subsequently added into the above solution under stirring for 30 min at $75^{\circ} \mathrm{C}$. The deinized water as the nonsolvent was finally added to precipitate a white micelles, which was continuously stirred until it became a clear and viscous solution. The resulting slurry was coated on the glass plate and immersed in the coagulation bath to precipitate the polymer membrane. The obtained membranes were washed with deinized water, and the residual solution on the surface was removed with filter paper and finally

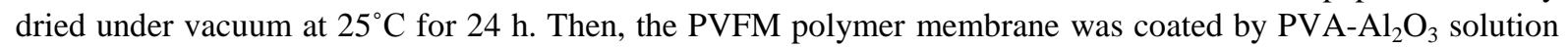
and dried under vacuum at $25^{\circ} \mathrm{C}$ for $24 \mathrm{~h}$.

\subsection{Preparation of the Gel Polymer Electrolytes}

$\mathrm{Al}_{2} \mathrm{O}_{3} / \mathrm{PVFM} / \mathrm{Al}_{2} \mathrm{O}_{3}$ trilayer membranes were punched into disks of $16 \mathrm{~mm}$ in diameter. Dropping a small amount of liquid electrolyte (1 $\mathrm{M} \mathrm{LiPF}_{6}$ in EC/DMC = 3:7 in vol, Beijing Institute of Chemical Reagent, China) to the surface of the polymer membranes in the argon-filled glove box in which the content of water and oxygen are less than $0.5 \mathrm{ppm}$, and then the liquid electrolyte penetrated into pores of membranes and swelled the polymer chains to form the GPEs.

\subsection{Test and Characterization}

Surface morphology was observed using field emission scanning electron microscope (FESEM) (Carl Zeiss, SUPRA55, Germany). Mechanical strength measurements were carried out on a tensile testing apparatus (INSTRON 5567 USA) at a crosshead speed of $10 \mathrm{~mm} / \mathrm{min}$, using the size of samples of $1 \mathrm{~cm} \times 3 \mathrm{~cm}$ at room temperature. To examine the thermal transition behaviour of the membrane, the samples were placed in an oven and heated at $150^{\circ} \mathrm{C}$ for $30 \mathrm{~min}$. The ionic conductivity of the GPE was determined by the symmetrical cell SS/ GPE/SS using EIS with potential amplitude of $5 \mathrm{mV}$ from $100 \mathrm{kHz}$ to $0.01 \mathrm{~Hz}$. The charge-discharge test was carried out using Land Battery Test System (LAND, CT2001A, China).

\section{Results and Discussion}

\subsection{Surface Morphology}

A schematic diagram of the trilayer membrane is presented in Figure 1. The cross-section and surface morphologies of the trilayer membrane as observed by FESEM, are given in Figure 2. $\mathrm{Al}_{2} \mathrm{O}_{3} / \mathrm{PVFM} / \mathrm{Al}_{2} \mathrm{O}_{3}$ trilayer membrane has apparent trilayer structure, as shown in Figure 2(a). The cross-section of PVFM based membrane presents sponge pores which promote the transportation of lithium ions, as shown in Figure 2(b). The inorganic particulate films have porous structures due to the distance between the $\mathrm{Al}_{2} \mathrm{O}_{3}$ particles, as shown in Figure 2(c). PVFM based membrane forms homogeneous pores, as shown in Figure 2(d).

\subsection{Mechanical Strength}

Considering the rigorous requirement in the battery manufacture, the mechanical property of a polymer should be considered for its use in GPE [11] [12]. Typical stress-deformation curves of PVFM and $\mathrm{Al}_{2} \mathrm{O}_{3} / \mathrm{PVFM} / \mathrm{Al}_{2} \mathrm{O}_{3}$ based membranes are shown in Figure 3. The mechanical strength of PVFM based porous membrane is increased from 1.29 $\mathrm{MPa}$ to 3.27 $\mathrm{MPa}$ through coating $\mathrm{PVA}-\mathrm{Al}_{2} \mathrm{O}_{3}$ solution onto both sides of the PVFM based membranes. The reinforcement in mechanical performance should be related to the $\mathrm{Al}_{2} \mathrm{O}_{3}$ that acts as temporary 


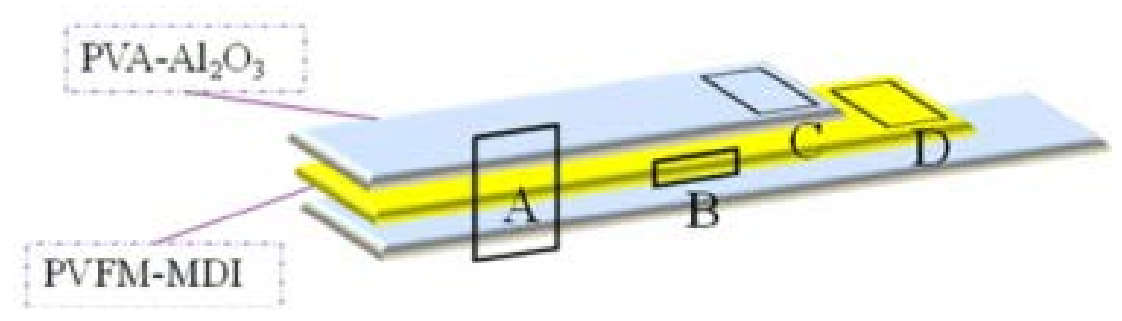

Figure 1. Schematic diagram of trilayer membrane.

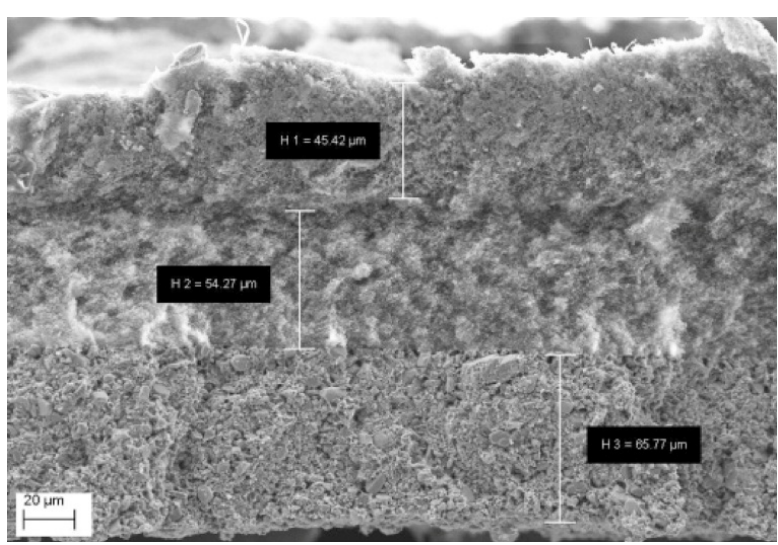

(a)

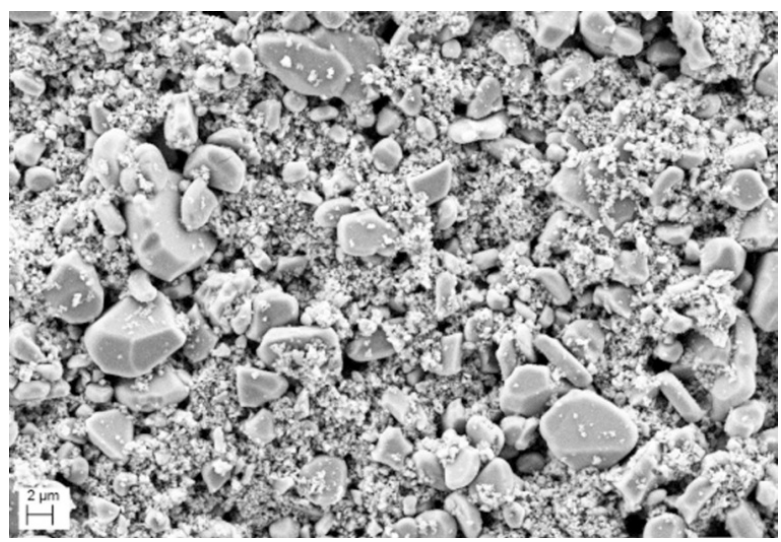

(c)

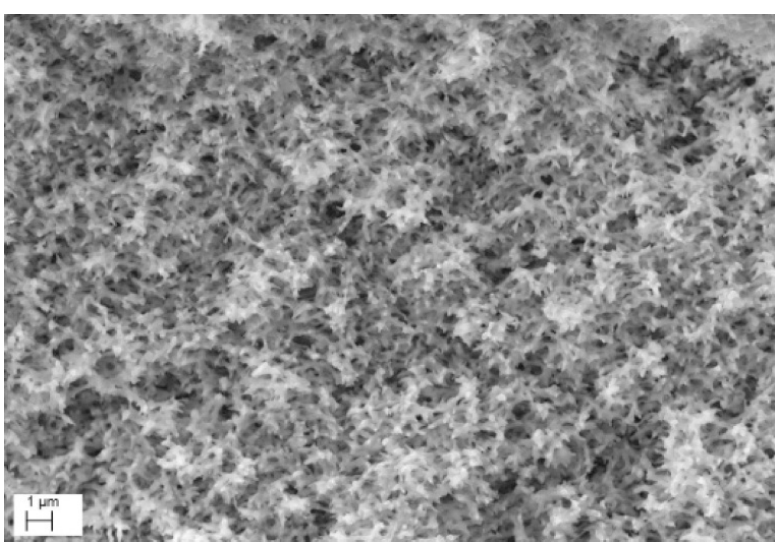

(b)

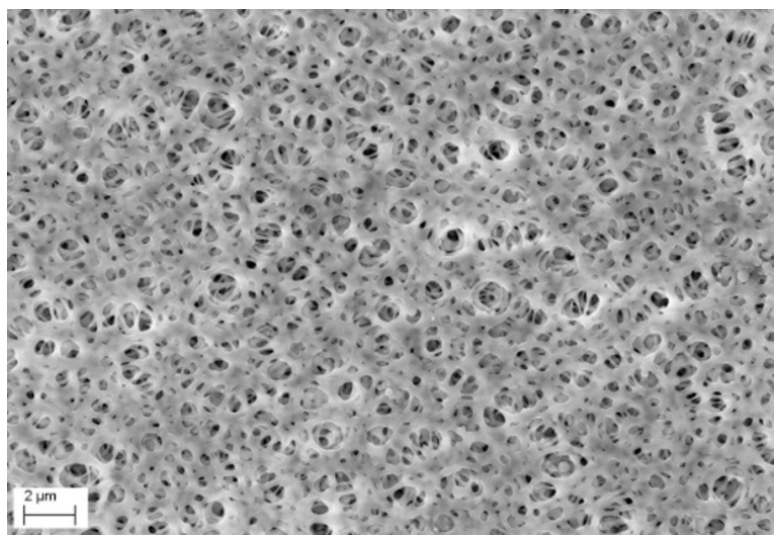

(d)

Figure 2. SEM images of $\mathrm{Al}_{2} \mathrm{O}_{3} / \mathrm{PVFM} / \mathrm{Al}_{2} \mathrm{O}_{3}$ trilayer membrane. (a) Cross-section $\mathrm{SEM}$ of $\mathrm{Al}_{2} \mathrm{O}_{3} / \mathrm{PVFM} / \mathrm{Al}_{2} \mathrm{O}_{3}$ trilayer membrane; (b) Cross-section SEM of PVFM based membrane; (c) Surface morphology of $\mathrm{Al}_{2} \mathrm{O}_{3}$ coating layer; (d) Surface morphology of PVFM based membrane.

mechanical connection point and enhances the strength of the membrane.

\subsection{Thermal Stability}

In lithium-ion batteries, the essential role of the separator is to prevent electronic contact, while enabling ionic transport between the cathode and the anode. Thus, the separators should be stable in the battery for a long period of time at high temperature [13]. In order to investigate the thermal-resistant characteristics of the trilayer membrane, thermal shrinkage behaviour is observed after storing the membranes at $150^{\circ} \mathrm{C}$ for 30 min. Photographs of the pure PVFM membrane and trilayer membrane before and after storage at $150^{\circ} \mathrm{C}$ for 30 min are given in Figure 4. It can be seen from Figure 4 that PVFM based porous membrane shows obvious curl and retention is $83 \%$. $\mathrm{Al}_{2} \mathrm{O}_{3} / \mathrm{PVFM} / \mathrm{Al}_{2} \mathrm{O}_{3}$ trilayer membrane shows no obvious curl and retention is $97 \%$. 


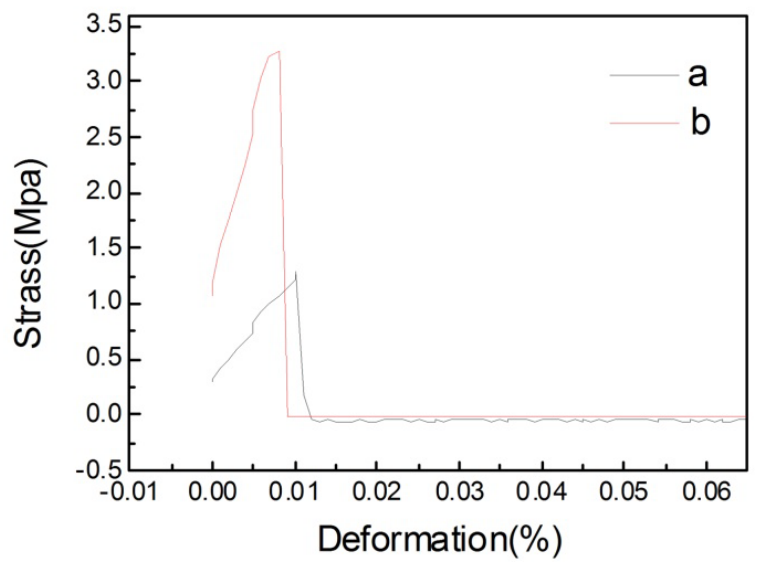

Figure 3. The stress-deformation curves of PVFM based membrane (a) and $\mathrm{Al}_{2} \mathrm{O}_{3} / \mathrm{PVFM} / \mathrm{Al}_{2} \mathrm{O}_{3}$ based membrane (b).

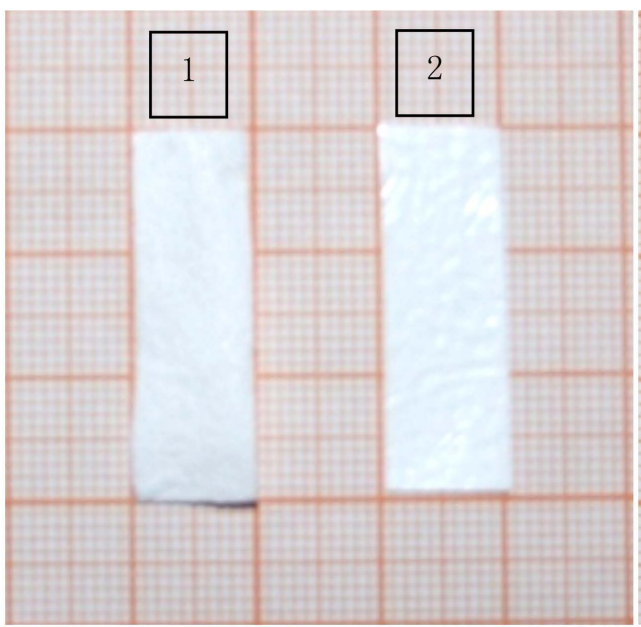

(a)

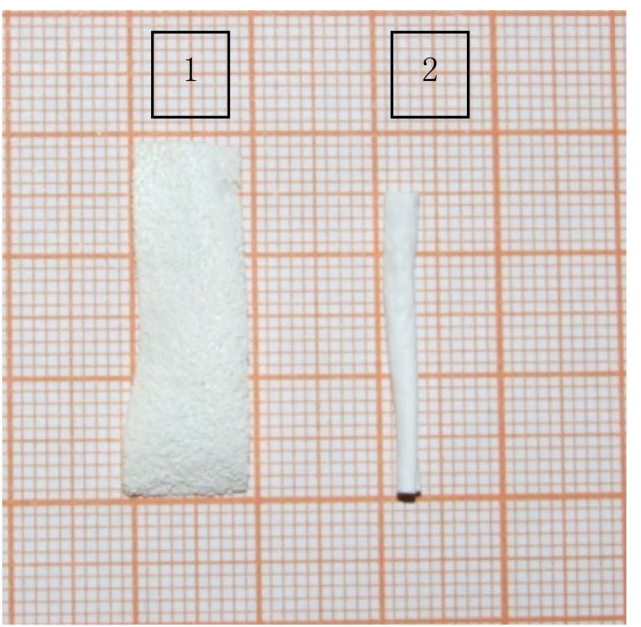

(b)

Figure 4. Photographs of membranes (a) before and (b) after being stored at $150^{\circ} \mathrm{C}$ for $30 \mathrm{~min}$. (1. $\mathrm{Al}_{2} \mathrm{O}_{3} / \mathrm{PVFM} / \mathrm{Al}_{2} \mathrm{O}_{3}$ trilayer membrane 2. PVFM based membrane).

\subsection{The Ionic Conductivity Behavior}

Figure 5 presents the Nyquist plot of the cells at room temperature. The ionic conductivity was calculated from the bulk electrolyte resistance using the following equation (Equation (1)) [14]:

$$
\sigma=\frac{L}{R \cdot S}
$$

where $L$ is the thickness of the GPE or separator, $S$ is the contact area between GPE or separator and SS disc, the bulk electrolyte resistance was obtained from the complex impedance diagram. Based on Equation (1), the obtained ionic conductivity of PVFM based GPE is $1.25 \times 10^{-3} \mathrm{~S} / \mathrm{cm}$. While the obtained ionic conductivity of $\mathrm{Al}_{2} \mathrm{O}_{3} / \mathrm{PVFM} / \mathrm{Al}_{2} \mathrm{O}_{3}$ based GPE is $4.13 \times 10^{-4} \mathrm{~S} / \mathrm{cm}$ and the obtained ionic conductivity of liquid electrolyte is $2.37 \times 10^{-4} \mathrm{~S} / \mathrm{cm}$. The decreased conductivity of $\mathrm{Al}_{2} \mathrm{O}_{3} / \mathrm{PVFM} / \mathrm{Al}_{2} \mathrm{O}_{3}$ based $\mathrm{GPE}$ is that the coating layer of $\mathrm{Al}_{2} \mathrm{O}_{3}$ particles blocks the routes for the lithium ions transportation, however it has a comparative ionic conductivity with liquid electrolyte, which can meet in the application of lithium-ion batteries.

\subsection{Battery Performance}

Figure 6 shows the discharge performance of the $\mathrm{Li} / \mathrm{LiFePO}$ half-cell using the $\mathrm{Al}_{2} \mathrm{O}_{3} / \mathrm{PVFM}_{4} / \mathrm{Al}_{2} \mathrm{O}_{3}$ based GPE 
at $0.2 \mathrm{C}$ from $2.5 \mathrm{~V}$ to $4.25 \mathrm{~V}$ at constant temperature of $25^{\circ} \mathrm{C}$. The discharge plateau is stable, showing small electrode polarization. Figure 7 presents the discharge capacities as a function of cycle number in the cells prepared with the liquid electrolyte and the gel polymer electrolytes, respectively. The initial discharge capacity density of the cell using the $\mathrm{Al}_{2} \mathrm{O}_{3} / \mathrm{PVFM} / \mathrm{Al}_{2} \mathrm{O}_{3}$ based GPE is $124.7 \mathrm{mAhg}^{-1}$. The discharge capacity density of the cell after 15th cycle is $140.3 \mathrm{mAhg}^{-1}$. Compared with liquid electrolyte, PVFM based GPEs including pure PVFM based GPE and $\mathrm{Al}_{2} \mathrm{O}_{3} / \mathrm{PVFM} / \mathrm{Al}_{2} \mathrm{O}_{3}$ based GPE show comparative cycling performance matched with electrodes $\mathrm{LiFePO}_{4}$.

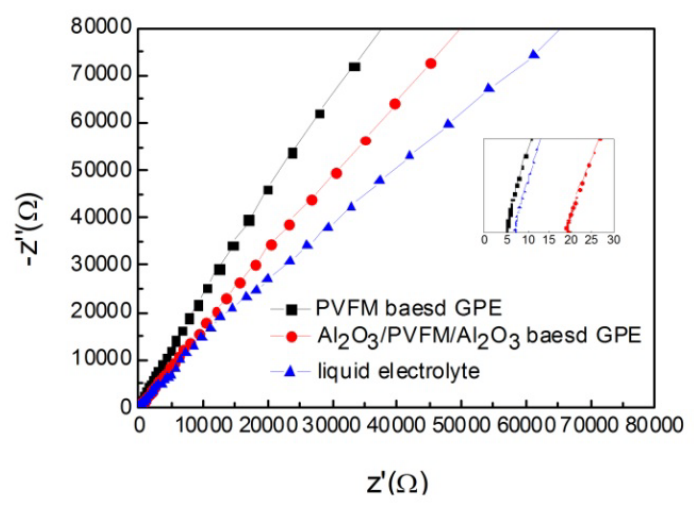

Figure 5. Nyquist plot of PVFM based GPE, $\mathrm{Al}_{2} \mathrm{O}_{3} / \mathrm{PVFM} / \mathrm{Al}_{2} \mathrm{O}_{3}$ based GPE and liquid electrolyte.

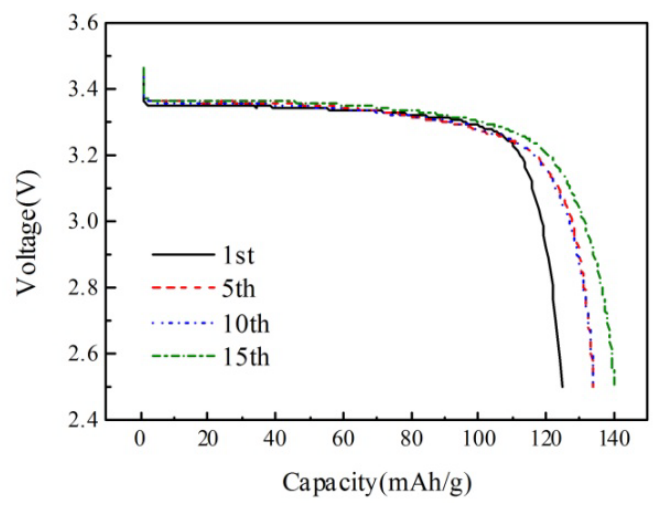

Figure 6. Discharge curves of the coin cell Li/ $/ \mathrm{Al}_{2} \mathrm{O}_{3} / \mathrm{PVFM} / \mathrm{Al}_{2} \mathrm{O}_{3}$ based $\mathrm{GPE} / \mathrm{LiFePO}_{4}$ at the $0.2 \mathrm{C}$ rate between $2.5 \mathrm{~V}$ and $4.25 \mathrm{~V}$.

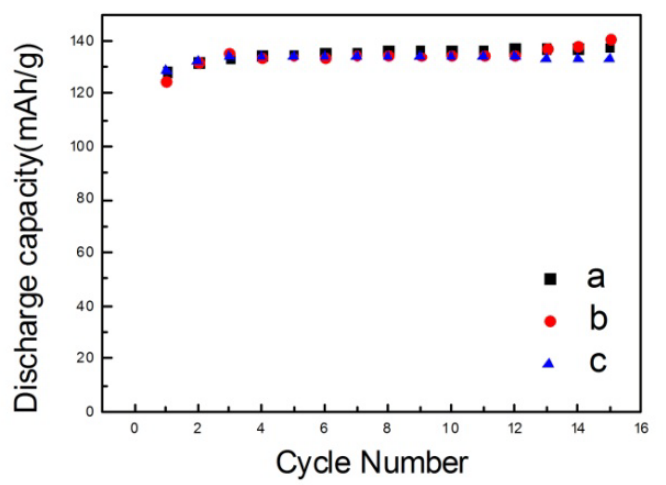

Figure 7. Cyclic stability of the coin cell (a) Li/liquid electrolyte/ $\mathrm{LiFePO}_{4}$, (b) $\mathrm{Li} / \mathrm{Al}_{2} \mathrm{O}_{3} / \mathrm{PVFM} / \mathrm{Al}_{2} \mathrm{O}_{3}$ based $\mathrm{GPE} / \mathrm{LiFePO}_{4}$ and (c) $\mathrm{Li} /$ PVFM based/LiFePO . 


\section{Conclusion}

An organic/inorganic trilayer membrane consisting of $\mathrm{Al}_{2} \mathrm{O}_{3} / \mathrm{PVFM} / \mathrm{Al}_{2} \mathrm{O}_{3}$ has been prepared. The membrane shows not only exceptional thermal integrity, but also enhanced mechanical properties due to the inorganic layers. Lithium ion cell with the $\mathrm{Al}_{2} \mathrm{O}_{3} / \mathrm{PVFM} / \mathrm{Al}_{2} \mathrm{O}_{3}$ based GPE matched with $\mathrm{LiFePO}_{4}$ shows excellent electrochemical performance. The results show that this unique multilayer polymer membrane is a promising candidate for separator applications in lithium ion batteries.

\section{References}

[1] Wen, Y., Lian, F., Ren, Y. and Guan, H.Y. (2014) Enhanced Electrochemical Properties of a Novel Polyvinyl Formal Membrane Supporting Gel Polymer Electrolyte by $\mathrm{Al}_{2} \mathrm{O}_{3}$ Modification. Journal of Polymer Science, Part B: Polymer Physics, 52, 572-577. http://dx.doi.org/10.1002/polb.23448

[2] Lian, F., Wen, Y., Ren, Y. and Guan, H.Y. (2014) A Novel PVB Based Polymer Membrane and Its Application in Gel Polymer Electrolytes for Lithium-Ion Batteries. Journal of Membrane Science, 456, $42-48$. http://dx.doi.org/10.1016/j.memsci.2014.01.010

[3] Song, J.Y., Wang, Y.Y. and Wan, C.C. (1999) Review of Gel-Type Polymer Electrolytes for Lithium-Ion Batteries. Journal of Power Sources, 77, 183-197. http://dx.doi.org/10.1016/S0378-7753(98)00193-1

[4] Cheng, C.L., Wan, C.C. and Wang, Y.Y. (2004) Preparation of Porous, Chemically Cross-Linked, PVdF-Based Gel Polymer Electrolytes for Rechargeable Lithium Batteries. Journal of Power Sources, 134, 202-210. http://dx.doi.org/10.1016/j.jpowsour.2004.03.037

[5] Kim, S.H., Choi, J.K. and Bae, Y.C. (2001) Mechanical Properties and Ionic Conductivity of Gel Polymer Electrolyte Based on Poly (Vinylidene-Fluoride-Co-Hexafluoropropylene). Journal of Applied Polymer Science, 81, 948-956. http://dx.doi.org/10.1002/app.1516

[6] Abraham, K.M., Alamgir, M. and Hoffman, D.K. (1995) Polymer Electrolytes Reinforced by Celgard® Membranes. Journal of the Electrochemical Society, 142, 683-687. http://dx.doi.org/10.1149/1.2048517

[7] Yarovoy, Y.K., Wang, H.P. and Wunder, S.L. (1999) Dynamic Mechanical Spectroscopy and Conductivity Studies of Gel Electrolytes Based on Stereocomplexed Poly(methyl methacrylate). Solid State Ionics, 118, 301-310. http://dx.doi.org/10.1016/S0167-2738(98)00442-1

[8] Kim, M., Han, G.Y., Yoon, K.J. and Park, J.H. (2010) Preparation of a Trilayer Separator and Its Application to Lithium-Ion Batteries. Journal of Power Sources, 195, 8302-8305. http://dx.doi.org/10.1016/j.jpowsour.2010.07.016

[9] Uchida, Y., Endo, T., Nakamura, T., et al. (2009) Polymer Electrolyte and Battery. US Patent No.2009/0202918 A1.

[10] Akio, H., Takashi, H. and Kuniyuki, T. (2005) Polyvinyl Acetal Resin Varnish Gelling Agent, Nonaqueous Electrolyte Solution, and Electrochemical Device. US Patent No.79531305A.

[11] Tian, Z., He, X., Pu, W., Wan, C. and Jiang, C. (2006) Preparation of Poly(acrylonitrile-butyl acrylate) Gel Electrolyte for Lithium-Ion Batteries. Electrochimica Acta, 52, 688-693. http://dx.doi.org/10.1016/j.electacta.2006.05.055

[12] Cheng, C.L., Wan, C.C., Wang, Y.Y. and Wu, M.S. (2005) Thermal Shutdown Behavior of PVdF-HFP Based Polymer Electrolytes Comprising Heat Sensitive Cross-Linkable Oligomers. Journal of Power Sources, 144, 238-243. http://dx.doi.org/10.1016/j.jpowsour.2004.12.043

[13] Arora, P. and Zhang, Z. (2004) Battery Separators. Chemical Reviews, 104, 4419-4462. http://dx.doi.org/10.1021/cr020738u

[14] Liao, Y.H., Li, X.P., Fu, C.H., Xu, R., Rao, M.M., Zhou, L., Hu, S.J. and Li, W.S. (2011) Performance Improvement of Polyethylene-Supported Poly(methyl methacrylate-vinyl acetate)-co-poly(ethylene glycol) Diacrylate Based Gel Polymer Electrolyte by Doping Nano- $\mathrm{Al}_{2} \mathrm{O}_{3}$. Journal of Power Sources, 196, 6723-6728.

http://dx.doi.org/10.1016/j.jpowsour.2010.11.036 